\title{
Contesting Civil Religion: Religious Responses to American Patriotic Nationalism, 1919-1929
}

\author{
Michael Lienesch
}

In the history of political thought, the concept of civil religion is both commonplace and controversial. Introduced by Machiavelli, Hobbes, and Spinoza, defined by Rousseau, revised by Tocqueville and Durkheim, it found its classic academic statement in the United States fifty years ago in Robert N. Bellah's "Civil Religion in America." In this celebrated essay, published originally in 1967 and cited since that time in more than 2,500 scholarly publications alone, Bellah characterized the concept as an "elaborate and well institutionalized" national faith, existing "alongside of and rather clearly differentiated from the churches," that "provides a transcendent goal for the political process." Although it drew on biblical archetypes, he described this American civil religion as "genuinely American and genuinely new," having "its own prophets and its own martyrs, its own sacred events and sacred places, its own solemn rituals and symbols." At the same time, he stressed that it was not a state religion, "not the worship of the American nation but an understanding of the American experience in the light of ultimate and universal reality." ${ }^{\prime 1}$ The definition was broad, complex, and ultimately unclear, but the essay was enormously provocative, inspiring a flood of commentary and continuing debates about the concept's meaning. ${ }^{2}$ It was also highly problematic, in that many readers misinterpreted it, assuming it to be a celebration of a chauvinistic form of religious nationalism that it was actually written to condemn. Indeed, by the late 1980s even Bellah himself had abandoned the term altogether, admitting that he had become "tired of arguing against those for whom civil religion means the idolatrous worship of the state." ${ }^{3}$

But the controversy over civil religion had taken on a life of its own. In the fifty years since publication of Bellah's classic piece, scholars have continued to comment on the topic, with interest in it rising and falling in distinct waves. Introduced amid the political turmoil of

Religion and American Culture: A Journal of Interpretation, Vol. 28, Issue 1, pp. 92-134, ISSN: 1052-1151, electronic ISSN: 1533-8568. ( 2018 by The Center for the Study of Religion and American Culture. All rights reserved. Please direct all requests for permission to photocopy or reproduce article content through the University of Califomia Press's Reprints and Permissions web page, http:/www.ucpress.edw/journals.php?p=reprints. DOI: https://oi.org/10.1525/rac.2018.28.1.92. 
the late 1960s, the idea remained controversial for well over a decade before beginning to disappear from sight during the Reagan era, only to be revived in the post- $9 / 11$ period, followed by further reassessments in light of the civil religious rhetoric of George W. Bush, Barack Obama, and Donald Trump. ${ }^{4}$ Over the last few years, there has been a marked renewal of interest in the concept, with a growing group of scholars coming to see it as critical to sustaining a sense of common purpose in an increasingly diverse democratic society. Indeed, in his American Covenant, the most recent revival of Bellah's concept, Philip Gorski has argued that civil religion is "perhaps the best starting point that we have for thinking about the future of America." ${ }^{5}$ Admittedly, some continue to make the case that the concept is counterproductive and should be abandoned altogether, but many others have begun to reexamine it seriously, albeit discussing it in ways that Catherine $L$. Albanese has described as "more chastened and circumspect, more complex and nuanced, more tentative than that of the past." ${ }^{\prime 6}$ These examinations have raised multiple issues, not only about how to conceptualize civil religion, but also about how to study it. Thus, Andrew $R$. Murphy for one has argued that while recent studies have made important contributions in analyzing its theoretical character, they have fallen short in examining its empirical features, or what he calls "the more localized and contested ground-level picture." Advocating a new approach, Murphy advises scholars to turn their attention to "both the macro and micro level," looking not only at the concept's broad philosophical outlines, but also at how it operates in "highly particular contexts." In short, he writes, the challenge going forward "is to find a way to bridge the theoretical analysis of American civil religion and the concrete details of American politics and society. ${ }^{7}$

This article is one attempt to build that bridge. It considers civil religion as theory and as practice, examining its meaning though an investigation of how it functioned at an important and too little studied point in its past. Arguing that civil religion is both a cultural and a political construct, it shows how at the close of World War I, a loosely linked network of civic, military, and patriotic groups came together to create a sacralized form of patriotic nationalism and incorporate it into the American civil religious tradition. Contending that the relationships between civil religion and more conventional forms of organized religion are often close and at times contentious, it examines how religious bodies of the time were instrumental in supporting this process and intractable in resisting it. Proposing that civil religion can come in a variety of sometimes competing versions, it discusses the conflicts over civil religious practices that ensued within American churches during the next decade, relying on reports from the time to 
describe how these conflicts divided church leaders, denominations, and congregations. Finally, working from the premise that civil religious beliefs, symbols, and rituals are invariably involved in the political process, it examines how they became increasingly used for partisan purposes over the course of the decade, raising issues about the relationship between church and state. In closing, it comments on the enduring character of civil religion and speculates on its continuing importance for American religion and politics.

\section{Constructing Civil Religion}

Arguments about civil religion begin with the question of how it comes to be constructed. In his 1967 essay, Bellah addressed the issue when he turned to Jean-Jacques Rousseau for the term, describing how Rousseau had defined it as a state-sponsored civic doctrine, a set of basic beliefs consciously created by public officials and conveyed to citizens in an effort to create unity and secure social order. ${ }^{8}$ Adopting Rousseau's term, he immediately proceeded to dismiss his definition of it, embracing instead one associated with the sociologist Emile Durkheim, who saw civil religion as the product of civic consciousness, arising spontaneously out of popular understandings of a people's highest and most transcendent values. ${ }^{9}$ In applying the concept to the United States, Bellah looked to presidential rhetoric, famously introducing his essay with John F. Kennedy's inaugural address, while also referring to those of Washington, Jefferson, Lincoln, and Johnson. At the same time, he made it clear that these speeches were best understood as ceremonical expressions of a deeper and wider cultural phenomenon, a shared set of beliefs, symbols, and rituals that comprised nothing less than a "religious dimension for the whole fabric of American life."10 Yet as the sociologist Marcela Cristi argues in an influential study, in adopting this Durkheimian definition of civil religion as a cultural construct, Bellah overlooked its Rousseauian roots as a political one. Specifically, Cristi contends that by defining the concept as the spontaneous expression of shared popular sentiments, Bellah failed to recognize that it can also be understood as an intentionally imposed ideology, or what she calls "a conscious tool to further political purposes." Furthermore, she goes on to show that Bellah's failure was not his alone, since many students of civil religion have continued to overlook its political character. Hence, Cristi concludes that if civil religion is to remain a useful concept, scholars must stop conceiving of it only in cultural terms, "as something that springs spontaneously from the culture itself, and spontaneously binds people together." Instead, she 
writes, it must be seen as "a phenomenon that is neither just civil, nor just religious, but also essentially political."11

At the end of World War I, civil religion emerged as a political issue in the United States. Following Bellah, students of the concept have commonly described it as being most visible during what he called "times of trial," meaning predominantly times of war, such as the American Revolution, the Civil War, and the international conflicts of the Cold War and the contemporary "War on Terror."12 As Raymond Haberski, Jr. argues, however, American civil religion has in fact been as evident after wars as during them, as citizens struggle to explain why so many had to fight and die, and as they seek ways to avoid future conflicts. Indeed, Haberski suggests that it is often in these postwar periods, when the state sanctioned unity of wartime has begun to fade, that debates over civil religion are most intense. ${ }^{13}$ Such was the case at the close of World War I. Throughout the war, encouraged by state agencies such as George Creel's Committee on Public Information (CPI), an unprecedented wave of patriotic zeal had swept the country, effectively silencing dissenting voices. ${ }^{14}$ At its end, popular support for the wartime cause had given way to disillusionment and discontent, as a weary public called for rapid demobilization, while labor and radical organizers demanded reforms to ease postwar recession and meet delayed demands for improving the lives of workers. Alarmed by the trends, critics across the country began to speak out, expressing fears of growing social unrest and political protest, while seeking new ways to maintain wartime order and unity in the postwar period. In a 1919 address to a group of fellow Kentucky business leaders, Frank N. Hartwell for one described Americans as "out of tune with their surroundings," "clamoring for their so-called rights," while "neglecting their duty." In these changed circumstances, he went on, what was needed was a different kind of patriotism, one based not on the immediate threat of external enemies, but on the continuing responsibility of citizens to demonstrate loyalty to the nation and obedience to its laws. Calling for the creation of this "peacetime patriotism," Hartwell proceeded to ask his audience to begin constructing it. "Let us be Americans to the core," he concluded, "upholding the Constitution, obeying the law and retaining loyalty to the flag." 15

But the creation of civil religion required more than rhetoric. To construct it, advocates had to organize, turning to civic associations to build its ideological and institutional foundations. In her critique of Bellah, Cristi argued that civil religion should be seen as a state sponsored ideology, consciously created and communicated by public officials acting to legitimate and stabilize the established political order. In fact, however, as N. J. Demerath III and Rhys H. Williams have 
maintained, it can be used as an ideological tool not only by state actors, but also by interest groups and social movements in pursuing their own political purposes. ${ }^{16}$ The postwar period provided a case in point. Throughout the war, federal officials had worked actively to mobilize existing voluntary organizations and create new ones in support of the war effort, constructing an elaborate associational infrastructure that reached into communites across the country. With demobilization, as federal agencies, boards, and coordinating committees were dismantled, many of these voluntary groups continued to carry on wartime campaigns while adapting them to peacetime purposes, including support for military preparedness, expanded benefits for veterans, and new programs to bolster and broaden popular patriotism. ${ }^{17}$ Among the most active of these groups were conservative business, civic, and professional associations (Better America Federation, National Civic Federation, American Bar Association), military and veterans organizations (National Security League, American Defense Society, American Legion, Veterans of Foreign Wars), and patriotic societies (Daughters of the American Revolution, Sons of the American Revolution). Together, they became the core of a loosely connected associational network that included not only national bodies (U.S. Flag Association, National Association for Constitutional Government), but also regional, state, and local ones (American Constitutional Association, Massachusetts Public Interest League, Sentinels of the Republic), along with an amalgamation of ad hoc alliances that were often the creation of individual entrepreneurs and organizers (Allied Patriotic Societies, Key Men of America, U.S. Patriotic Society). Operating independently, their activities often overlapped and at times came into conflict, and several attempts at institutional coordination proved unsuccessful. Nevertheless, over the next decade, they would come together repeatedly, meeting in national conferences, citing and reprinting one another's publications, and cooperating closely in a loosely coordinated campaign to create what one observer of the time called "unquestioning loyalty to American institutions as they exist today." ${ }^{18}$

Their efforts were remarkably ambitious. Adopting methods to influence public opinion like those used by the CPI's Division of Civic and Educational Cooperation, cooperating with federal agencies including the War Department and the fledgling Bureau of Investigation, working closely with sympathetic national and state legislators, activists associated with these groups launched campaigns designed to convey the ideology of peacetime patriotism to the general public and to institutionalize it in a variety of ways. Thus, beginning in the early 1920s, encouraged by the National Americanism Commission of the American Legion, representatives of some sixty-eight organizations met in a series 
of National Flag Conferences to establish rules for the display of the American flag, standardize the wording of the Pledge of Allegiance, and lobby for the adoption of "The Star Spangled Banner" as the national anthem. ${ }^{19}$ Business associations like California's Better America Federation sponsored patriotic essay and oratory contests for schoolchildren, advocated laws that required the teaching of celebratory versions of the nation's history and political institutions, and carried out investigations of "un-American" texts and disloyal teachers in the public schools. ${ }^{20}$ Military, veterans, and patriotic societies sponsored commemorations of national and state holidays and lobbied to establish a long list of new ones. ${ }^{21}$ In addition, in an extraordinarily successful collaboration, the National Security League, the National Association for Constitutional Government (NACG), and the American Bar Association (ABA) worked together to assure allegiance to the American Constitution by sponsoring celebrations of Constitution Day and Constitution Week, distributing millions of copies of the document, and lobbying states to pass laws requiring its teaching, so that by the end of the decade all but five states had mandated Constitution courses in their public schools. ${ }^{22}$

In these campaigns, advocates commonly described themselves as constructing a form of civic faith. In World War I, federal agencies and publications had actively encouraged the use of religious rhetoric and symbolism to build popular support for wartime sacrifice. At its end, civic associations took up a similar role, making the case that if the country was to thrive in peacetime, citizens would have to demonstrate the same kind of spiritual devotion to the nation that they had shown during the war. ${ }^{23}$ In the words of Garland W. Powell, national director of the American Legion's Americanism Commission, postwar citizenship required nothing less than "undying devotion to, faith in, and service to the United States of America." ${ }^{24}$ Throughout the early 1920s, association activists and leaders elaborated on the theme, stressing the similarities between political loyalty and religious faith. Hence, in a 1922 report, members of the ABA's Committee on American Citizenship made the case that patriotism could not be taught "by merely imparting information," since like religion, it was "of the spirit and of the heart. ${ }^{25}$ Some made the connection even more explicit. The authority of the American state, insisted James M. Beck, a leader of the NACG, required that citizens exhibit an attitude of reverence toward their government, viewing it with "a deep and abiding respect akin to a religious feeling." ${ }^{26} \mathrm{~A}$ few went so far as to describe citizenship in confessional and even liturgical terms, depicting it as closely parallel to church membership. Citizens should be expected to learn the "articles of our political faith," observed U.S. Appeals Court judge 
and San Francisco civic leader William W. Morrow in a speech to law students at the University of California, "as we do the Ten Commandments or the Lord's Prayer or the litany of the church to which we belong. ${ }^{\prime 27}$ All agreed that public schools had the responsibility not only to educate students in the principles of patriotism, but also to instill in them an abiding faith in the American form of government. As the ABA Citizenship Committee concluded, "The schools of America should no more consider graduating a student who lacks faith in our government than a school of theology should consider graduating a minister who lacks faith in God."28

In constructing this civic faith, its architects embraced existing articles of American civil religion while also adapting them to current circumstances and devising new ones. Here their efforts were by no means unprecedented. From Bellah on, scholars have described civil religion in the United States as an evolving tradition, present from the country's first founding, that has been continually renewed and revised since then. In this regard, Gorski has described it as a multigenerational project, an "ongoing effort" taking place "within the confines of a particular historical trajectory. ${ }^{\prime 29}$ In the 1920 s, advocates of civic faith were eager to place themselves within an existing American civil religious tradition, regularly recycling the rhetoric of canonical civic texts, as when the American Legion's Powell, writing in his Service for God and Country, quoted Abraham Lincoln's 1838 Springfield Lyceum address on the importance of making "reverence for the laws" into "the political religion of the nation." ${ }^{30}$ More often, they adapted existing aspects of American civil religion, updating them for the modern mass public, and disseminating them through multiple media outlets. Thus, calling the Constitution "our holy of holies," they flooded the schools with textbooks that instructed students to read it with reverence, "the same reverent spirt we would have if we were entering upon some holy shrine. ${ }^{31}$ Declaring the American flag a "sacred thing," they established uniform rules for how to display it, complete with directions on how to hang, fold, and salute it. ${ }^{32}$ Extolling historical heroes as "objects and tenets of religious worship," they sponsored public observances of their birthdays, while also initiating investigations of school textbooks that criticized or questioned their character. ${ }^{33}$ In addition, they promoted new articles of civic faith, such as William Tyler Page's popular "The American's Creed," a statement modeled on the Apostles' Creed, distributing it in book form, printing it in their newsletters and magazines, and inviting audiences to recite it at patriotic programs. ${ }^{34}$ They also devised new civil religious rituals, organizing public celebrations that closely emulated worship services, with invocations, benedictions, creedal statements, patriotic hymns, and public prayers. 
(At the 1921 Constitution Day ceremonies in Louisville, Kentucky, whistles and bells sounded throughout the city at the noon hour, and citizens were asked to silently pray "I am an American citizen. God help me to do my duty as such." ${ }^{35}$ ) In short, they constructed, communicated, and put into practice nothing less than their own fully formed version of American civil religion, designed to command the devotion of citizens of every religious persuasion. After all, wrote the editors of the American Legion Weekly, patriotism was a subject "that lends itself with equal appeal to every creed and denomination."

\section{Civil Religion in the Churches ${ }^{37}$}

Although civil religion and sectarian religion are decidedly different concepts, the line between them is in practice not always as sharp as in theory. In his 1967 essay, Bellah attempted to draw a clear distinction between the two, arguing that while American civil religion was "selectively derived" from Christianity, it was "clearly differentiated" from it. ${ }^{38}$ Yet as religious historians led by Sidney Mead, Conrad Cherry, Ernest Tuveson, and others have pointed out, biblical prophecy, Calvinist theology, and Protestant moral teaching have combined repeatedly with secular strains of republicanism to give civil religion in the United States a distinctly Christian character. ${ }^{39}$ Indeed, because clergy and churches have played such a prominent role in constructing and conveying it, some scholars have argued that American civil religion is nothing more than a Judeo-Christian form of religious nationalism, a "hybrid," as Haberski calls it, "of nationalism and traditional religion." ${ }^{\prime 40}$ Others have gone even further, with the cultural anthropologist Michael Angrosino proposing that it has "displayed persistent elements of theism and even theocracy." ${ }^{41}$ The argument can be overstated, and most of those who study civil religion would agree that in the United States the absence of a state church and the presence of religious pluralism have meant that it has taken on an identity distinct from any traditional church or denomination. Even so, those such as John D. Wilsey have suggested that more needs to be done to chart the connections between civil and organized religion in the United States. To use Wilsey's words, it remains to be shown how it happens that while American churches "have not served as the sources of civil religion," they have so often "served as agents... to support and advance it." ${ }^{\prime 2}$

In fact, religious institutions played a central role in advancing civil religion in the postwar period. Throughout the nation's history, churches had been sponsoring services celebrating public holidays and 
honoring those who had died in the country's wars. In World War I, sometimes responding to popular pressure, many of them became active contributors to the war cause, decorating their sanctuaries with American flags and service banners honoring congregants serving in the military. ${ }^{43}$ So it was predictable that at the close of the war advocates of peacetime patriotism would turn again to the churches, calling on them to be even more active in building loyalty to the nation. Military and veterans groups asked clergy to serve as post chaplains, established church cadet corps, and provided speakers for Sunday schools and religious youth groups. ${ }^{44}$ Patriotic organizations sponsored special church services to celebrate Independence Day, Constitution Day, Flag Day, and Washington's Birthday. ${ }^{45}$

Some groups worked to create their own civil religious observances. As early as 1919, for example, the American Legion was calling on clergy across the country to sponsor American Legion Sunday, during which they were requested to devote part of their sermons "to the ideals for which the American Legion stands." ${ }^{\prime \prime 6}$ In 1922, the American Constitutional Association, a business organization with an antiunion agenda, announced America First Day, to be held on the Sundays on or immediately before July 4 , during which churchgoers would "renew their pledges of patriotism" in order to overcome the forces that "threaten the very essence of organized society, and law and order." ${ }^{\prime 47}$ A year later, the Allied Patriotic Societies, an amalgamation of antiradical and nativist groups, issued a resolution inviting each of the state governors to proclaim the fourth Sunday of January as Law and Order Sunday, and "calling the people to meet in their respective churches and listen to an explanation of the wonderful privileges which they enjoy under the Constitution of the United States." The purpose of the proclamations, explained the organization's president, was "so that the whole country will join to combat the influence of the Reds and Revolutionists." ${ }^{48}$ Civic clubs and fraternal groups encouraged ministers to preach patriotic sermons and presented churches and synagogues with flags to display in their sanctuaries. ${ }^{49}$ In 1923, the New Jersey Society of the Sons of the American Revolution released a report recommending that clergy in that state see to it that patriotic rituals be observed not just on civic holidays but at every regular service, and that "the Flag of Stars and Stripes be presented at the altar of churches following the offertory or some other point in the service, and that 'America' be sung."

Many congregations eagerly embraced such requests. Indeed, in churches across the country, civil and conventional religion combined seamlessly. Armistice Day brought worship services with military personnel delivering the sermons, members of patriotic and 
veterans groups comprising much of the congregation, and sometimes "pews being banked almost solidly with standards of every hue, the red, white and blue of the Stars and Stripes predominating." ${ }^{151}$ Fourth of July services included tableaus of the signing of the Declaration of Independence, complete with choirs in colonial costume.$^{52}$ On Constitution Day, preachers recited its preamble from their pulpits and delivered sermons on "the sacredness of our blood-bought Constitution." In Indiana, no fewer than two hundred fifty churches participated in American Legion Sunday in its first year alone. ${ }^{54}$ In West Virginia, Sunday school superintendents reported several thousand celebrations of America First Day, with numbers growing steadily during the early 1920 s. $^{55}$ Some congregations added their own civic celebrations, like the First Methodist Church of Los Angeles' homegrown America Day, in which "all addresses and music will be in keeping with the spirit of patriotism." ${ }^{\prime 56}$ In South Carolina, American Legion National Commander Alvin M. Owsley appeared on stage alongside the evangelist Billy Sunday when he delivered his popular "Americanism" sermon, in which he advised audiences to "stand by God, Christ and country." ${ }^{157}$ Observers reported that such celebrations had become not just commonplace, but pervasive. "In nearly every church," declared the Los Angeles Times in 1927, "at least one service will be devoted to Memorial Day themes, with musical programs of patriotic character." ${ }^{258}$

In many of these congregations, civil religion was an exercise in religious nationalism. In their speeches and sermons, advocates regularly blurred the lines between God and country, and in some cases, erased them completely. Thus, in a 1923 Memorial Day sermon delivered to a congregation that included President and Mrs. Harding, John Brittan Clark of Washington's First Presbyterian Church explained how the curtain in the Hebrew temple had been spiritually transformed into the American flag, creating a holy relic, "red, white, and blue; forever behind it the Eternal God." ${ }^{59}$ Preaching on Independence Day in 1926 in New York City, John N. Wolf of the National Bible Institute recalled how in signing the Declaration of Independence, the country's founders had "expressed their faith in God and the gospel of His dear Son. ${ }^{\prime 60}$ In a Baltimore Constitution Day sermon, DeWitt Benham of that city's Central Presbyterian Church described the original document as "conceived and written in the spirit of Christianity" and its amendments as "illustrations of the union of Christianity and government. ${ }^{\prime 61}$ At Episcopal churches across the country, Washington's Birthday was regularly commemorated by congregations praying the historically suspect "Washington's prayer," which Bishop James E. Freeman of Washington called a reminder of "the spiritual basis of the nation's greatness." ${ }^{\prime 2}$ When questions arose about the presence of flags 
in sanctuaries, patriotic groups minimized them. As the American Legion's Powell explained, church banners could not be displayed more prominently than the Stars and Stripes, since the nation's flag "symbolizes Christianity itself. It stands for God and country."63 Many church leaders concurred. "There is no sacrilege in keeping the flag and the Bible together," explained James I. Vance in his Flag Day sermon to Nashville's First Presbyterian Church, "for the flag proclaims what the Bible commands, and so, in the name of our God, we will set up our banner." 64

\section{Varieties of Civil Religion}

Nonetheless, American civil religion has never consisted of religious nationalism alone. Writing in 1967, Bellah had assumed the presence of a single civic faith, the product of what he described as a single religious-political tradition and a single founding myth. Although he would later revise this view, he persisted in seeing civil religion in hegemonic terms, as the product of a common (albeit often broken) national covenant. ${ }^{65}$ By contrast, others have made the case that the concept can take multiple forms, as part of a "broad, dynamic field of contending forces," as Ira Chernus has put it, "rather than an imagined unified tradition." ${ }^{\prime \prime 6}$ Writing in 1988, Robert Wuthnow proposed that in the United States there were two separate civil religions: a conservative "priestly" one that existed to provide divine sanction to America's economy, form of government, and privileged place in the world; and a liberal "prophetic" one that raised questions about its way of life, scrutinized its economic and political policies, and challenged its citizens to act on behalf of humanity rather than in their own interests alone. ${ }^{67}$ Since that time, others have elaborated on the existence of these two strains, while also suggesting additional ones. Grace Y. Kao and Jerome E. Copulsky, for example, have isolated four distinct understandings of civil religion-preservationist, pluralist, priestly, prophetic-which they see as operating independently to legitimate the social order in the United States. ${ }^{68}$ Others have suggested even more variations. The historian Arthur Remillard, for example, has found that different versions of civil religious discourse existed among a wide variety of social groups in the post-Reconstruction South. ${ }^{69}$ Admittedly, some analysts continue to speak of civil religion as a single unified tradition. Yet to study it this way, say Demerath and Williams, is "an enterprise in scholasticism." Instead, they propose, scholars must take seriously how "specific groups and subcultures use versions of the civil religion to frame, articulate, and legitimate their own particular political and moral visions." 70 
In the 1920s, American civil religion was far from a unified tradition. Before the war, many clergy had spoken out strongly against policies of military preparedness, warning their congregations of the dangers posed by American entry into foreign hostilities. At its end, many more, including some who had confidently declared the conflict to be a holy crusade, took to their pulpits to express regret at the millions of lives and billions of dollars lost in what in retrospect seemed like a godless exercise. ${ }^{71}$ In some churches, ministers welcomed the peace by quietly removing wartime symbols from their sanctuaries and services. As the Reverend J. W. Shepherd of the Detroit Church of Christ explained in 1920, the end of the war meant that the church could now "hear other songs than 'The Star Spangled Banner' and 'My Country, 'Tis of Thee' in her assemblies, and see other sights than the 'consecration, with imposing religious ceremonies' of 'service flags' and of the 'banners' of warriors on her altars!" 72

In 1921, at the first ceremony honoring the Unknown Soldier, the Federal Council of Churches sponsored a service in the Capitol Rotunda where Union Theological Seminary's William Adams Brown pointedly reminded attending dignitaries that "patriotism is not enough" and called for a "wider citizenship, a fellowship in which all the peoples of mankind may share. ${ }^{\prime 73}$ The following year, the Federal Council's Commission on International Justice and Goodwill asked member churches to desist from celebrating what it called the "military phases of Armistice Day," observing the holiday instead with confessions of sin for their complicity in war, along with prayers "that war may really be banished from the earth." ${ }^{174}$ Even at the end of the decade, pacifist pastors like the Unitarian John Haynes Holmes were condemning the commemoration of Memorial Day as a military holiday, since it "restores the memory of disgraceful wars and glorifies their ignoble causes." Instead, Holmes suggested that the day be observed with services of solemn mourning, complete with "parades of black-robed mothers through the streets, mourning the dead so futiley dead. ${ }^{\prime 75}$ In the historic peace churches, patriotic celebrations of any kind were strictly avoided if not actively condemned, while Mennonites and other groups drew a sharp line between church and state by refusing to participate in public rituals like saluting the flag. ${ }^{76}$ As the Quaker activist Frederick J. Libby explained to the 1928 Friends General Conference, patriotism meant nationalism, and nationalism was "the greatest enemy of Christianity." 77

While some antiwar activists renounced civil religion of any kind, however, others embraced it, developing alternative forms designed to promote peace rather than war. Throughout the early postwar period, antiwar sentiment would build steadily in America's churches, 
with almost every major Protestant denomination, North and South, along with Catholic and Jewish organizations passing resolutions calling for disarmament, demanding limits on military expenditures, and endorsing American membership in the League of Nations and the World Court. $^{78}$ In 1921, the Protestant Federal Council of Churches, working with the National Catholic Welfare Conference and the Association of Jewish Rabbis, presented petitions signed by more than 20,000 clergy calling on Harding to convene the Washington Naval Conference on arms reductions. ${ }^{79}$ Adopting methods used by the American Legion, the Federal Council in 1921 announced its "campaign for a warless world," inviting the President and governors of the states to proclaim Armistice Day of that year as a day of prayer for the Washington Conference, while also encouraging churches to sponsor special services and mass community meetings on the importance of international peace. ${ }^{80}$ The ecumenical Church Peace Union asked ministers to sponsor Disarmament Sunday services, with special sermons and prayers on the topic, and urged congregations to send resolutions advocating disarmament to their Congressional representatives. ${ }^{81}$

With the ratification of arms agreements in 1922, the Federal Council sent out a request to towns and cities across the country to declare days of celebration. "Parades, banners, floats and every device for arousing popular patriotic enthusiasm," advised the Federal Council Bulletin, "which have been so effectively used in support of war, should now be brought into the service of the war against war." ${ }^{82}$ The following year, when American entry into the Permanent Court of International Justice stalled in the Senate, the Council asked its members to observe Armistice Sunday as World Court Sunday, mounting a nationwide program of meetings, petitions, and resolutions that included "tens of thousands of sermons dealing with world problems, world peace and the World Court." ${ }^{183}$

Others crafted customized versions of civil religion that addressed a range of social and economic issues. Throughout the early 1920s, religious reformers initiated campaigns to deal with a long list of public policy issues that had been placed on hold during the war. Such efforts were often framed as patriotic exercises, with the rhetoric and symbolism of civil religion providing support for a variety of progressive causes. Thus, in 1922, Christian Endeavor Society Secretary A. B. Kendall proposed a Citizenship Day program that included the singing of patriotic songs and the recitation of an early version of the pledge to the flag, combined with the inspirational message that "true patriotism" consisted of being a "true reformer." ${ }^{84}$ Preachers gave sermons celebrating ratification of the suffrage amendment, describing the American woman as now "holding in her hand the divine 
right of the ballot." ${ }^{85}$ Congregations invited state and local labor leaders to speak from their pulpits and address their Sunday schools on Labor Sunday and Child Labor Sunday. ${ }^{86}$ African American church leaders celebrated Lincoln's Birthday as Anti-Lynching Day, calling for prayer and penitence, along with stronger antilynching laws. ${ }^{87}$ World federalist Bruce Brown, pastor of South Park Christian Church in Los Angeles, gave a 1923 Flag Day sermon in which he recast the American flag as an international symbol. "When the United States of America shall become a part of the United States of the World," predicted Brown, "the banner of our fathers will symbolize liberty and justice for all mankind." 88

Modernist ministers constructed reformist rituals of civic faith. The Unitarian reformer Charles Francis Potter even went so far as to announce plans for a new "all-American Bible" featuring the words of Washington, Adams, and Jefferson as the "American Pentateuch," Jane Addams as "our modern Deborah leading in the warfare against social wrong," and Lincoln as America's "social Christ." As Potter described it, the new Bible would also include books based on the teachings of a selection of American social reformers, "our Amoses, Isaiahs, Micahs and Hoseas," who "not only had the advantage of all that the Hebrew prophets said," but also "met the problems that are nearer us today." The new civic scripture was clearly designed to attract an audience that reached beyond church-goers to include all citizens. After all, explained Potter, "if we are to have the Bible taught in our American schools, let it be the American Bible." ${ }^{\prime 89}$

\section{Conflict in the Churches}

Although those who study civil religion almost always admit that it must be understood as a complex concept, they have often resisted the argument that it is also a contested one. Beginning with Bellah, advocates have seen it as a source of unity, creating harmony and solidarity around shared civic values. In his American Covenant, Gorski makes a strong case that it can serve as a kind of overlapping consensus between diverse religious and political constituencies, binding them together in a continuing conversation about America's meaning and purpose. ${ }^{90}$ Nevertheless, critics have warned that any civic faith not only runs the risk of achieving consensus by excluding those who disagree from participating in it, but also overlooks the continuing conflict, or what Rhys Williams calls the "tug of war," between included and excluded groups. ${ }^{91}$ Moreover, as a growing cohort of religious historians has shown, American civil religion has never 
been completely consensual or harmonious. Indeed, as Jonathan D. Sarna argues, any conception of civil religion that presupposes such consensus "flies in the face of observed reality." Throughout the nation's history, Sarna contends, debates over civil religion have generated "highly charged conflicts," reflecting "deep seated cultural differences" that have "set Americans at odds with one another." Especially over the last several decades, with growing religious diversity and increasing political polarization, such conflicts have become even more common. Thus, he makes the case for an approach to the study of civil religion that is based less on the ideal of consensus than on the reality of conflict. "Instead of a single civil religion harmoniously uniting all Americans," Sarna concludes, "an alternative hypothesis rooted in the pervasive sense of cultural conflict that characterizes much of America's past seems, in the eyes of a new generation, far more persuasive." ${ }^{92}$

Throughout the 1920s, civil religion was a contentious issue in American churches. On Armistice Day, there were military processions in some congregations and solemn prayers for world peace in others. Independence Day brought dueling sermons. In 1926, on the sesquicentennial of the signing of the Declaration of Independence, Monsignor Michael Lavelle of New York's St. Patrick's Cathedral called the document a "miracle of God's providence," while across town John Haynes Holmes was describing it to listeners at his Community Church as "sanctified, and therefore petrified," and suggesting that a "New Declaration" was needed to "treat present-day capitalistic control as the forefathers did political monarchy." ${ }^{\prime 93}$ In some churches Memorial Day Sunday featured services honoring members of the American Legion, Grand Army of the Republic, and Veterans of Foreign Wars, while in others it was commemorated as Peace Day, complete with recitation of the "International Creed." ${ }^{94}$ Occasionally, congregations staged competing celebrations, as happened in 1929 when Child Labor Sunday and Law and Order Sunday fell on the same date. ${ }^{95}$ Add to this that some parishes avoided civic ceremonies altogether, forgoing commemorations of Flag Day to honor fathers on Father's Day or observing the religious holidays prescribed by their ecclesiastical calendars. ${ }^{96}$ A few tried to please everyone at once, as in 1925 at New York's Cathedral of St. John the Divine, where a service celebrating the $150^{\text {th }}$ anniversary of the Battle of Lexington featured an array of battle flags symbolizing the country's wars massed in front of the altar and a sermon on the topic of how "we must learn to love our enemies."97

With civil religion taking such decidedly different forms, the predictable result was conflict. At the close of the war, civic commemorations seemed often to merge celebrations of victory with prayers for lasting peace. By the mid-1920s, however, tensions between these 
themes were evident. Thus, in 1924, when the War Department proposed a National Defense Day, honoring those in the armed services while also testing the ability of civilian and military forces to mobilize in future wars, peace activists in the churches responded scornfully, with leaders like Frederick Brown Harris of New York's Grace Methodist Church denouncing the plan as "bluster, bluff and bunting." 98 As protests from church bodies poured into Washington, the Army General Staff proceeded to make matters worse by proposing that future Defense Days be set to coincide with Armistice Day. This time church leaders reacted with outrage, deriding the proposal as an attempt to recast a commemoration of wartime sacrifice into a promotion of peacetime military preparedness, as well as part of a deliberate plan to "counteract and crush the peace movement.".99

With advocates of preparedness and advocates of peace increasingly at odds, clashes became inevitable. When local veterans groups refused to participate in the dedication of a flagpole on the grounds of a Presbyterian church in New Jersey because it had a pacifist passage from Isaiah engraved on it ("Nation shall not lift up sword against nation; neither shall they learn war any more"), peace activists had had enough. "And now it seems that even the Bible is not to be quoted in public places and in connection with patriotic memorials if forsooth the particular quotations do not meet the approval of some of these self-lauded patriots," wrote the Herald of Gospel Liberty. "This sort of thing has been permitted to drag along altogether too long, and some of the members of our patriotic organizations have been the worst offenders in it." 100

Alarmed by pacifism's growing popularity, critics went on the offensive. Throughout the 1920s, military and veterans groups took the lead in depicting religious pacifists as unpatriotic and even subversive. As early as 1920, Father Francis A. Kelley, chaplain general of the Army and national chaplain of the American Legion, was describing pacifism as one of Bolshevism's "co-isms," while also asserting that there was "only one 'ism' for this country, and that is the '100 per cent Americanism' of the American Legion. ${ }^{\prime 101}$ In 1924, when Northwestern University's Epworth League held a service presided over by a pacifist speaker in which dozens of college students pledged not to fight in future wars, local veterans groups convened a mass meeting in which three thousand participants, singing "The Star Spangled Banner" and "Onward Christian Soldiers," protested their "disrespect of the flag and the American Legion." ${ }^{102}$ Two years later, Legion leaders in North Carolina, charging that the Federal Council of Churches was sending speakers to the state who were suspected of "pacifist or communistic leanings," called on members to stop them from spreading their "unpatriotic propaganda." 
Pacifism was not the only danger. Pointing to church social programs to bring about industrial reform, the National Civic Federation published extensive reports warning that communists, socialists, and "other subversive elements" were gaining a foothold in the Presbyterian, Episcopal, and Methodist churches, as well as in the Catholic Welfare Council, the YMCA, and other parachurch groups, where they were actively promoting "uneconomic, unpatriotic and atheistic doctrines." 104 Patriotic societies singled out religious leaders as involved in subversive activities. Thus, in 1928, it was revealed that the Daughters of the American Revolution had been distributing "blacklists" naming scores of seditious persons, including many prominent ministers, priests, and rabbis. ${ }^{105}$ Self-styled patriots chimed in as well, as when Captain George L. Darte, adjutant general of the Military Order of the World War, demanded that Columbia University sociologist Carlton J. H. Hayes, a convert to Catholicism who had described modern nationalism as a political religion with its own symbols and rituals, be "kicked out of the university bodily" for expressing "disrespect of the flag and the Liberty Bell."106 Meanwhile, in communities across the country, children were being removed from the public schools for refusing to salute the flag or recite the Pledge of Allegiance. ${ }^{107}$

As the attacks intensified, conservative church leaders took a leading role in challenging the patriotism of their liberal counterparts. Pacifism in particular came in for criticism. Hawkish clerics condemned Armistice Day messages that called for limits on military expenditures. "Jesus never taught or insinuated that it was wrong to be a soldier," insisted Gustav Stearns, a Lutheran minister and chaplain of the Wisconsin American Legion. "He Himself used force when he used lashes to drive grafters from the temple." ${ }^{108}$ When peace activists rallied against Defense Day, an ecumenical group of religious leaders organized by the War Department issued statements supporting military preparedness and calling on their fellow ministers to renounce what they called "the indiscriminate advocacy of radical pacifism."109 Mixing charges of pacifism and radicalism, the popular evangelical preacher Gordon Palmer told a 1924 audience listening on radio station KHJ in Los Angeles that "un-American Americans," acting "under the guise of religion," were seeking "the destruction of our civilization"110 Quoting reports from antiradical groups, those in the new fundamentalist movement questioned the loyalty of liberal religious organizations, describing the views of the Federal Council of Churches, in the words of Theodore Graebner, a leading voice in the Missouri Synod Lutheran Church, as "un-Christian and almost treasonable." ${ }^{111}$ Some fundamentalists pulled no punches in portraying religious progressives as both heretics and traitors, "self-constituted prophets," as the Moody Monthly 
put it, "who would have us turn our backs on our flag to follow after their strange gods." 112

For their part, religious progressives fought back. In scores of sermons, liberal and modernist preachers took to their pulpits to counter conservative and fundamentalist views of the meaning of patriotism. Describing the American Legion's slogan of "100 per cent Americanism" as "the most abused expression of the last five years," Universalist minister Frank D. Adams called it "a bludgeon in the hands of tyrants to beat down loyal conscience, and a gag to throttle free expression." ${ }^{113}$ Others distinguished "lower" and "higher" forms of patriotism, with liberal lions like J. V. Moldenhawer of New York City's First Presbyterian Church describing the slogan "my country, right or wrong" as needing to be "purified and developed lest its coarse and uncouth qualities, common to boys and barbarians, mark it as unfit for civilized society." ${ }^{\prime 14}$ Church conferences condemned attacks on clergy who had spoken out against war and in favor of social reform. ${ }^{115}$ The Federal Council of Churches released a report on "patriotic propaganda," deploring how it had been used to defame "everyone who has incurred the displeasure of the propagandists," including many of "the honored leaders of the churches." ${ }^{16}$ "When the DAR blacklist was made public, a furious Harry Emerson Fosdick announced that he would like to be added to it. "If the D.A.R. is going to have a blacklist, one would pray to be on it," he told his congregation at New York's Park Avenue Baptist Church; "to be on their whitelist would be a disgrace." 117 Charles Francis Potter agreed, declaring that "if Jesus Christ were to return today he would be on the black list of the Daughters of the American Revolution." Branding members of the organization "political fundamentalists," Potter urged his congregation to condemn their views, lest they "soon be announcing the verbal inspiration of the Constitution and the Virgin birth of George Washington." ${ }^{118}$

Not surprisingly, the contests over civil religion turned churches against themselves. Throughout the 1920s, state and national meetings of mainline Protestant denominations became sites of controversy, as resolutions concerning patriotism and peace provoked deep divisions and fierce floor fights. ${ }^{119}$ Matters dealing with civil religious symbols and rituals were especially fraught. As early as 1919, Episcopal Bishop J. B. Cheshire of North Carolina created a storm of indignation at the triennial General Convention of the Episcopal House of Bishops when he offered resolutions to remove "The Star Spangled Banner" and "America" from the church hymnal, objecting to what he called the "worship of standards, as in the Roman empire," and arguing that hymns should be "addressed to Almighty God" and not "to a flag." ${ }^{120}$ In 1926, Methodist Bishop Francis J. McConnell, a prominent 
social reformer, provoked angry criticism when he told a church conference that "the American flag should never be nailed above the cross," explaining that he meant it was wrong "to support a particular policy of the Government simply because the Government sponsored it." ${ }^{121}$ When the Episcopal House of Bishops voted to incorporate a special July 4 service into its 1928 revision of the Book of Common Prayer, the proposal passed over strenuous opposition by a single vote. ${ }^{122}$ Church leaders squabbled publicly. For example, when Acting Bishop Paul Jones of the Episcopal Diocese of Southern Ohio told a 1929 Boston Navy Day rally that the display of the American flag in school rooms constituted a "dangerous fetish worship which promotes thoughts of war among school children," Washington's Bishop Freeman expressed his outrage in a letter to the Washington Post, boasting that "in most of the Episcopal churches in the country the flag is either carried in procession or else adorns the chancel." ${ }^{123}$ Perhaps most painful were the debates that took place in local congregations, which sometimes pitted pastors against their own congregations. Thus, in 1925, W. M. Yeomans, a Presbyterian minister in Reading, Pennsylvania, resigned in protest of the decision to place an American flag at the side of the church pulpit, explaining that he was unable to preach "near a symbol of an authority that makes war possible." According to news reports, the church "unanimously approved his departure."124

\section{Politicizing Civil Religion}

Ultimately, civil religion raises questions concerning the role of religion in the political process. From Bellah on, scholars have insisted that it be seen as an autonomous belief system, influenced by but separate from not only organized religion but also the secular state. Indeed, Philip Hammond has argued that civil religion proper can exist only in modern secularizing societies where religious and political spheres are clearly differentiated. ${ }^{125}$ Public opinion studies by Ronald C. Wimberley and James A. Christenson have found that popular attitudes about civil religion do not run counter to the idea of separation of church and state and that in the United States there is what they call "a coexistence of the two types of beliefs." ${ }^{126}$ At the same time, however, Wimberley and Christenson have shown that these same attitudes can strongly predict citizen preferences for political candidates and public policies. ${ }^{127}$ In addition, a steadily growing number of studies have demonstrated that civil religion has provided rhetorical and other symbolic resources used by activists and leaders in electoral campaigns, 
protest movements, and policy debates. ${ }^{128}$ Thus, many scholars today have come to see it as invariably involved in the political process. In the words of Amanda Porterfield, American civil religion must be considered to be "inevitably partisan." 129

Throughout the 1920s, civil religion became increasingly politicized, and as a result, increasingly polarized in American churches. In broad terms, church-centered celebrations of national holidays were always political, in that they mixed religious and political beliefs and symbols into hybrid forms of civic faith. Often they were political in a more specific sense as well, with ministers using the occasions to make the case for public policies ranging from Sabbatarianism to the prevention of child labor. Admittedly, many clergy went out of their way to draw distinctions between religious and political views, while avoiding partisan positions when possible. As Herbert Booth Smith told his congregation at Immanuel Presbyterian Church in Los Angeles, "We need more patriotism and less politics, for politics is patriotism minus vision. Today's patriotism," he averred, "needs large vision, Christian vision, else it degenerates into selfish partisan politics." ${ }^{130}$ Nevertheless, for many others, the task of advocating patriotism while avoiding politics-let alone partisanship-sometimes proved impossible. After all, as Methodist minister F. A. Frye would explain to a 1920 Illinois camp meeting, to his mind "there are only three great documents in the world today, and they are the decalogue, the constitution of the United States, and the platform of the Republican party." ${ }^{\prime 131}$

An early example of civil religion's potential for politicization came in 1924, when churches across the country joined in the "GetOut-the-Vote" campaign, a nationwide patriotic program created to increase voter turnout in the presidential election of that year. Sponsored by a score of business and civic organizations, and making use of multiple media to reach potential voters, the campaign relied heavily on religious groups to convey its message of civic participation. The Homiletic Review, a periodical sold primarily to Protestant clergy, announced a "Get-Out-the-Christian-Vote" project, in which pastors promised to seek 100 percent voter turnout in their congregations. ${ }^{132}$ Working through its Commission on Social Service, the Federal Council of Churches also took a leading role, with its secretary Worth M. Tippy asking pastors to preach "election sermons," not only on the Sunday preceding Election Day, but "from Sunday to Sunday until election day," reminding their congregations to "register 100 per cent" and to "vote 100 per cent." 133 In constructing their campaign in the churches, organizers drew heavily on existing civil religious practices while also establishing new ones, encouraging ministers to sponsor special Citizenship Sunday services that featured civic rituals in which first time voters were initiated and 
instructed that "the duties of a citizen are sacramental."134 On Election Day, some churches held patriotic services, while others rang bells and "those having chimes played 'The Star-Spangled Banner."'135 The results of the 1924 election were disappointing, with overall voter turnout remaining about the same as four years earlier. Moreover, in retrospect, critics described the campaign as a thinly disguised effort to encourage white middle-class voters to offset the growing power of immigrant and working class political machines. Some observers noted that while it purported to be nonpartisan, the campaign appeared to work to the benefit of President Coolidge in fending off the challenge of Progressive Party presidential candidate Robert M. La Follette. ${ }^{136}$ Even so, organizers hailed the campaign as a success, calling on church leaders to continue it in future elections, so as not to permit, in the words of the Homiletic Review, "the fostered warmth of a really Christian patriotism, to cool and die." 137

Then there was Prohibition. In the 1920s, the issue took on the character of a patriotic crusade in many Protestant churches, with civil religion being repeatedly called on to bolster the cause. Constitution Day sermons, with their pleas for obedience to the law of the land, were often less about the Constitution than its Eighteenth Amendment and related laws prohibiting the sale of alcoholic beverages. At its 1920 national conference in Washington, the Anti-Saloon League announced that the Sunday following Constitution Day would be celebrated as Second Constitution Day, on which its ministerial members would give sermons demanding active enforcement of the anti-alcohol Volstead Act. ${ }^{138}$ Others put other holidays to the same use, as when Episcopal Bishop William T. Manning used his 1925 Washington's Birthday sermon to call for observing the law of the land, since "the person who violates the prohibition laws is not a good citizen or a patriot." ${ }^{\prime 139}$ Over the course of the decade, church-based campaigns in support of Prohibition became steadily more political, even as their sponsors insisted that they were not political at all. In 1928, for example, the Anti-Saloon League announced an impromptu Citizenship Sunday for October 28 of that year, asking clergy to mark the occasion by reminding their congregations of their duty to vote for Prohibition candidates in the impending November elections. "Any activity that will increase the percentage of voters and help inform them on the vital issues of the campaign is not politics," explained League Superintendent F. Scott McBride. "It is patriotism."140 The following year, when President Hoover called for a national movement to support the strict enforcement of Prohibition, churches across the country joined with civic groups to sponsor community-wide Loyalty Sunday rallies like the one held at the Hollywood Bowl, where an audience of ten 
thousand citizens, right hands raised, recited an oath of obedience to the Constitution and "all the laws of the land," while also swearing "especially to abstain from the purchase of intoxicating liquors for beverage purposes." ${ }^{141}$ Prohibitionists like Ruth Bryan Owen, daughter of the late William Jennings Bryan, went even further, telling a Washington mass meeting that the Pledge of Allegiance itself ought to be amended to include a phrase supporting Prohibition, with citizens affirming that "every law for which my flag stands will be sacred to me."142

With the election of 1928, civil religion became hopelessly entangled in party politics. For America's churches, the election was especially contentious. Protestant preachers played an unusually active role in the campaign, particularly in the South, where many denounced Democratic presidential candidate Al Smith for his opposition to Prohibition, and where some openly declared that his Roman Catholicism disqualified him to be President. At the extreme, there were those who preached the exclusivist version of Americanism advocated by the $\mathrm{Ku}$ Klux Klan, whose members comprised substantial parts of Protestant church congregations in many parts of the country and who on occasion arrived at services wearing white robes and carrying American and Klan flags. ${ }^{143}$ More frequently, Smith opponents turned to a Constitutioncentered version of civil religion to make their case. As Methodist Bishop Adna W. Leonard explained, "No Governor who kisses the papal ring can be elected President," since "as Americans, we recognize one supreme authority, the Constitution of the United States, which under God was written by the fathers of our country." ${ }^{144}$ As the election approached, anti-Smith clerics, denying both religious bigotry and political partisanship, doubled down on the allegation that he was lacking in patriotism. Thus, the Los Angeles Baptist John Snape described the real issue in the election as "not religion, nor tariff, not agriculture, immigration, economy, party or prohibition," but "love and loyalty to the Constitution" and "love for America." 145 By the close of the campaign, some preachers had so commingled patriotism and partisanship that their worship services seemed indistinguishable from Republican political rallies. Preaching at the First Congregational Church in Washington only days before the election, the evangelist Billy Sunday, surrounded by children waving the American flag, concluded his sermon by calling on voters to "save the boys and girls of the country by casting their ballots against Smith Tuesday." ${ }^{146}$

Yet civil religion could work to the benefit of more than one political party. Thus, even as some religious leaders relied on civil religious symbols and rituals to rationalize exclusion, others used them to advocate for a more inclusive idea of citizenship. In 1927, 
for example, as part of the sesquicentennial observance of the adoption of the American flag, a "vesper flag service" was held on the steps of the United States Capitol, complete with sacred and patriotic music by the Marine Corps Band, the singing of hymns by a choir of a thousand voices, and an address on "The Religion of the Flag." 147 Heartily endorsing the event, Protestant, Catholic, and Jewish leaders issued a joint statement commending the ceremony for bringing together "all creeds, denominations and classes" to "uphold the ideals, traditions and institutions for which the flag stands." ${ }^{\prime 48}$ Throughout the following year, Protestant clergy continued to use commemorations of national holidays to promote religious freedom and political unity. ${ }^{149}$ As the election approached, their statements became more pointed, as when Bishop Charles Anderson of Chicago decried the religious intolerance that had appeared in the presidential race, reminding the 1928 Episcopal General Convention of "America's most precious possession, religious liberty," the ideal that had inspired "the Pilgrim fathers," "the cavaliers of Jamestown," and "the valiant men who settled Maryland under the Catholic Lord Baltimore." ${ }^{150}$ Jewish leaders such as Rabbi Stephen S. Wise also spoke out strongly, calling on Protestant clerics to declare that anti-Catholicism was "a sin against America and religion alike." ${ }^{151}$ Catholics were even more vocal in condemning intolerance. "We have been assailed as unpatriotic, un-American," Father John C. Mulcahy told a Columbus Day mass held on the baseball field at Fordham University weeks before the election. Those who question our loyalty, he asserted, must be taught that "the crowning glory of Catholics is their American patriotism." ${ }^{152}$ In each case, the message was that religious inclusion was central to America's civic faith. "The light of religious tolerance," asserted Presbyterian pastor Henry van Dyke, in a statement published by the Democratic National Committee, "glows like a sacred and undying fire on the high altar of the Constitution." ${ }^{153}$

Following the election of 1928, American civil religion seemed to become less politically polarized. The election had divided churches and congregations, and in its wake denominational leaders issued statements advising their churches to retreat from ecclesiastical involvement in partisan politics. ${ }^{154}$ Celebrations of national holidays continued to flourish, attracting large crowds to public meetings and parades, but the events were less ideologically loaded and the speeches less divisive. ${ }^{155}$ Appearances notwithstanding, however, civil religion remained a politically charged issue. On the Sunday before Hoover's inauguration in 1929, Protestant ministers across the country led special prayers for the new President, reminding their congregations of their duty "to support their Chief Executive as loyally when he assumes the reins of government as they did in placing him at the helm of the 'Ship of State." ${ }^{\prime \prime 156}$ The 
following Memorial Day, while some preachers offered prayers for the President, others took to their pulpits to chastise him, demanding "a public confession from the President down that the nation has sinned in committing war." ${ }^{157}$

In each case, civil religion remained a rich political resource. Moreover, it was a resource that was adaptable to changing situations. Thus, in November of 1929 , a few days following the stock market crash of that year, Governor Franklin D. Roosevelt addressed a New York City church congregation that included forty units representing military, veterans, and patriotic groups on the tenth anniversary of Armistice Day. Praising the groups for their service, Roosevelt proceeded to caution them that the duty of the patriot was to fight not only against military enemies but also moral ones, including "the evil forces of greed, of materialism, of selfishness, headed by those who cynically deny that there is any prosperity or goodness that cannot be expressed in dollars and cents, or happiness except in bank balances." In closing, he called on the assembled to be "good soldiers of the faith," fighting "militantly, tirelessly" against these moral enemies. "Your flags have rallied around your country's banner. Make that no empty symbol," he concluded. "Move forward in your banner's path and underneath this, our country's symbol, consecrate yourselves to defend not only your nation's boundaries, but your nation's soul, lest freedom and justice, equality and liberty should perish from the earth." 158

\section{Conclusion}

Over the last fifty years, scholars following in the footsteps of Robert Bellah have described the future of American civil religion in surprisingly tenuous terms. Writing at the end of the 1960s, Bellah himself sounded a note of uncertainty about the ability of Americans to adapt the concept to the changing realities of a revolutionary world. By 1975, he had declared it hopelessly fractured, its vision of a coherent consensus about America's identity and purpose having become only an "empty and broken shell." 159 Since that time, many observers have depicted American civil religion as in retreat, its ability to create cultural cohesion imperiled by democratic dissent and multicultural diversity. Indeed, some have argued that with globalization, nationstates have lost the capacity to generate collective identity, leading to the collapse of civil religion into exclusionary expressions of national and subnational tribalism. ${ }^{160}$ Increasingly, however, with the revival of patriotic rituals in response to acts of terrorism and continuing international conflict, scholars have come to revise earlier views about the 
enervated character of civic religion. Indeed, among those who study the concept, many no longer think of it as a fixed and fragile faith, but rather as an elastic and resilient one, capable of being constantly transformed in response to changing political circumstances. To understand civil religion today, as Wade Clark Roof has put it, is to see it as "a more fluid, contested, and evolving symbolic construction." ${ }^{\prime 161}$

At the close of the 1920s, civil religion did not disappear. Instead, it has continued to be adapted and developed since that time. Over the last century, it has been repeatedly revised: with the official adoption of "The Star Spangled Banner" as the national anthem in 1931, of "In God We Trust" as the national motto in 1956, and of the authorized form of the Pledge of Allegiance in 1942 (along with the addition of the phrase "under God" in 1954); with the creation of new memorials, new national holidays, and new rituals like the September 11 services held each year at the 9/11 Memorial Museum; and with the appearance of rhetorical practices such as the closing benediction to presidential speeches of "God Bless the United States of America."162 In its many variations, civil religious discourse has been embraced by both critics and friends of the New Deal in the 1930s and 1940s, by anticommunist crusaders and civil rights activists in the 1950s and 1960s, by culture warriors and antinuclear protesters in the 1980s, and by supporters and opponents of the "War on Terror" in the early twenty-first century. ${ }^{163}$ Over that time, it has remained a hotly contested topic in America's cultural politics, as seen in bitter debates over Bible reading and prayer in the public schools, the posting of the Ten Commandments in courthouses and public buildings, and the presence of "under God" in the Pledge of Allegiance. ${ }^{164}$ At the same time, it has been a recurrent theme in U.S. foreign policy as well, inspiring both support for and opposition to the nation's involvement in conflicts from Vietnam to Iraq and Afghanistan. ${ }^{165}$ Today, champions of civil religion from many sides continue to debate its multiple meanings, as seen in controversies such as those involving the location of the "Ground Zero mosque," the removal of Confederate symbols and monuments, and the protests of athletes during the singing of the national anthem at sports events. ${ }^{166}$

For the future, civil religion promises to persist. As in the past, it will be reasserted and revised. With increasing diversity of religious and political views, attention will continue to be drawn to existing proposals to remove state and national holidays such as Christmas and Columbus Day or to add new ones honoring figures such as Susan B. Anthony, Cesar Chavez, or Malcolm X. Court challenges are certain to proliferate, testing the constitutionality of the pledge to the flag, sectarian prayers at presidential inaugurals and public meetings, and 
proclamations of ceremonial occasions like the National Day of Prayer. In debates over immigration, activists and politicians will persist in using the rhetoric of civil religion for political purposes, to support priestly forms of exclusionary exceptionalism and to inspire prophetic visions of egalitarianism and inclusivity. In future wars, including conflicts against terrorism, its symbols will sanction violence and inspire selfless sacrifice. Religious leaders will take sides supporting and opposing its rituals, as will nontheists and nonbelievers. And while Robert Bellah would surely protest, civil religion will continue to be debated by scholars of religion and politics for another fifty years and beyond.

\section{Notes}

For their comments and encouragement on earlier versions of this work, the author wishes to thank Kevin M. Kruse, Melissa Matthes, Andrew R. Murphy, David Sehat, Joel Winkelman, Molly Worthen, and the anonymous referees at Religion and American Culture.

1. See Robert N. Bellah, "Civil Religion in America," Daedalus 96 (1967): 1; 4; 18. For background on the concept, see Ronald Beiner, Cizil Religion: A Dialogue in the History of Political Philosophy (Cambridge, U.K.: Cambridge University Press, 2011).

2. On the early "civil religion debate," see American Civil Religion, ed. Russell E. Richey and Donald G. Jones (New York: Harper \& Row, 1974). See also Matteo Bortolini, "The Trap of Intellectual Success: Robert N. Bellah, the American Civil Religion Debate, and the Sociology of Knowledge," Theory and Society 41 (2012): 187-210.

3. Robert N. Bellah, "Comment," Sociological Analysis 50 (1989): 147. See also Robert N. Bellah, The Broken Covenant: American Civil Religion in a Time of Trial (New York: Seabury Press, 1989), 139-63.

4. For an overview of the debate, see Phillip Hammond, "The Sociology of ACR: A Bibliographic Essay," Sociological Analysis 37 (1976): 169-82; Gail Gehrig, "The American Civil Religion Debate: A Source for Theory Construction," Journal for the Scientific Study of Religion 20 (1981): 51-63; James A. Mathison, "Twenty Years after Bellah: Whatever Happened to American Civil Religion?" Sociological Analysis 50 (1989): 129-46; Phillip E. Hammond, "Forum: American Civil Religion Revisited," Religion and American Culture 4 (1994): 1-23; and Michael Angrosino, "Civil Religion Redux," Anthropological Quarterly 75 (2002): 239-67. For more recent applications, see Jose Santiago, "From 'Civil Religion' to Nationalism as the 
Religion of Modern Times: Rethinking a Complex Relationship," Journal for the Scientific Study of Religion 48 (2009): 394-401; Wade Clark Roof, "American Presidential Rhetoric from Ronald Reagan to George W. Bush: Another Look at Civil Religion," Social Compass 56 (2009): 286-301; Philip S. Gorski, "Barack Obama and Civil Religion," Political Power and Social Theory 22 (2011): 177-211; Rhys H. Williams and Todd Nicholas Fuist, "Civil Religion and National Politics in a Neoliberal Era," Sociology Compass 8 (2014): 929-38; and Michael Kazin, "Trump's Civil Religion Has an Angry God," Foreign Policy, January 20, 2017, http://foreignpolicy.com/2017/01/20/ trumps-civil-religion-has-an-angry-god-inauguration-populism/.

5. Philip Gorski, American Covenant: A History of Civil Religion from the Puritans to the Present (Princeton, N.J.: Princeton University Press, 2017), 13.

6. Catherine L. Albanese, "Echoes of American Civil Religion," The Immanent Frame, February 12, 2010, http://blogs.ssrc.org/tif/2010/02/12/ american-civil-religion/. See also essays by Richard Amesbury, Philip S. Gorski, David Kyuman Kim, Pamela Klassen, Ebrahim Moosa, David Morgan, and George Shulman in "Reconsidering Civil Religion," The Immanent Frame, 2010, http://blogs.ssrc.org/tif/reconsidering-civil-religion/. Recent collections on the topic include Holy Nations and Global Identities: Civil Religion, Nationalism, and Globalisation, ed. Annika Hvithamar, Margit Warburg, and Brian Arly Jacobson (Leiden, The Netherlands: Brill, 2009); Civil Religion in Political Thought: Its Perennial Questions and Enduring Relevance in North America, ed. Ronald Weed and John von Heyking (Washington, D.C.: Catholic University of America Press, 2012); and The Rhetoric of American Civil Religion: Symbols, Sinners, and Saints, ed. Jason A. Edwards and Joseph M. Valenzano IIl (Lanham, Md.: Lexington Books, 2016).

7. Andrew R. Murphy, "Civil Religion for a Diverse Polity," Political Power and Social Theory 22 (2011): 231; 233.

8. See Bellah, "Civil Religion in America," 5-6. See also JeanJacques Rousseau, On the Social Contract, trans. and ed. Donald A. Kress (Indianapolis: Hackett Publishing Co., 1987), 96-103.

9. For Bellah on Durkheim, see Robert N. Bellah, "Durkheim and Ritual," in The Cambridge Companion to Durkheim, ed. Jeffrey C. Alexander and Philip Smith (Cambridge, U.K.: Cambridge University Press, 2005), 183-210. See also Emile Durkheim, The Elementary Forms of Religious Life (New York: Free Press, 1915), 474-79.

10. Bellah, "Civil Religion in America," 3-4. 
11. Marcela Cristi, From Civil to Political Religion (Waterloo, Ont.: Wilfrid Laurier University Press, 2001), 12; 13.

12. See Bellah, "Civil Religion in America," 16-19.

13. See Raymond Haberski, Jr., God and War: American Civil Religion since 1945 (New Brunswick, N.J.: Rutgers University Press, 2012), 11-12.

14. On the Committee on Public Information, see Stephen Vaughan, Holding Fast the Inner Lines: Democracy, Nationalism, and the Committee on Public Information (Chapel Hill: University of North Carolina Press, 1980).

15. "Would Reduce Public Offices," (Louisville) Courier-Journal, December 11, 1919.

16. See N. J. Demerath III and Rhys H. Williams, "Civil Religion in an Uncivil Society," Annals of the American Academy of Political and Social Science 480 (1985): 154-66. See also Cristi, From Civil to Political Religion, $224-30$.

17. On the proliferation of civic associations in the postwar period, see Theda Skocpol, Ziad Munson, Andrew Karch, and Bayliss Camp, "Patriotic Partnerships: Why Great Wars Nourished American Civic Voluntarism," in Shaped by War and Trade: International Influences on American Political Development, ed. Ira Katznelson and Martin Shefter (Princeton, N.J.: Princeton University Press, 2002), 151-69.

18. Bessie Louise Pierce, Citizens' Organizations and the Cioic Training of Youth (New York: Charles Scribner's Sons, 1933), 3. For a discussion of these and related groups, see also Norman Hapgood, Professional Patriots (New York: Albert \& Charles Boni, 1928); Kim E. Nielsen, Un-American Womanhood: Antiradicalism, Antifeminism, and the First Red Scare (Columbus: Ohio State University Press, 2001); and Kirsten Marie Delegard, Battling Miss Bolsheviki: The Origins of Female Conservatism in the United States (Philadelphia: University of Pennsylvania Press, 2012).

19. See Richard J. Ellis, To the Flag: The Unlikely History of the Pledge of Allegiance (Lawrence: University Press of Kansas, 2005), 50-80.

20. See Howard K. Beale, Are American Teachers Free? An Analysis of Restraints upon the Freedom of Teaching in American Schools (New York: Charles Scribner's Sons, 1936), 523-29.

21. See Bessie Louise Pierce, Public Opinion and the Teaching of History in the United States.(New York: Alfred A. Knopf, 1926), 93-98. 
22. See Michael G. Kammen, A Machine That Would Go of Itself: The Constitution in American Culture (New York: Alfred A. Knopf, 1986), 232. See also Michael Lienesch, "Creating Constitutional Conservatism," Polity (2016): 387-413.

23. See Jonathan H. Ebel, Faith in the Fight: Religion and the American Soldier in the Great War (Princeton, N.J.: Princeton University Press, 2010).

24. Garland W. Powell, Service for God and Country (Indianapolis: Cornelius Printing Co., [1924]), 7.

25. "Report of the Committee on American Citizenship," Annual Report of the American Bar Association 45 (1922): 421.

26. James M. Beck, "A Rising or a Setting Sun?" Constitutional Review 8 (1924): 14.

27. William W. Morrow, "The Americanism of the Constitution of the United States," Constitutional Review 4 (1920): 32.

28. "Report of the Committee on American Citizenship," 421.

29. Gorski, American Covenant, 222. See also ibid., 30-36.

30. Powell, Service for God and Country, 142.

31. "Calls Constitution 'Our Holy of Holies,'" New York Times, March 7, 1928; Martin J. Wade and William F. Russell, The Short Constitution (Iowa City: American Citizen Publishing Co., 1921), 207.

32. Powell, Service for God and Country, 44. On the National Flag Conferences, see Ellis, To the Flag, 50-80. Meeting yearly, the Flag Conferences also concentrated on transforming Francis Bellamy's earlier version of the pledge into the nation's "Pledge to the Flag," making changes to the wording and providing a uniform salute (right hand "extended, palm upward, toward the Flag"). See ibid., 65-67. In addition, inspired by President Harding's complaint that too many citizens did not know the words to "The Star Spangled Banner," conference activists began what would become an eight-year effort to have the song officially declared the national anthem. See ibid., 62-63.

33. W. I. Lincoln Adams, "The Proper Teaching of History," Official Bulletin of the National Society of the Sons of the American Revolution 17 (December 1922): 19. On textbook investigations, see Pierce, Public Opinion, 254-68. 
34. See [William Tyler Page], The Book of the American's Creed ([Garden City, N.Y.]: Country Life Press, 1921). The book was "Issued Under the Auspices of National Patriotic Organizations." The Sons of the American Revolution sold "tastefully printed" copies of the creed at the price of $\$ 4.00$ per hundred and $\$ 30.00$ per thousand. "Announcements," Official Bulletin of the National Society of the Sons of the American Revolution 16 (October 1921): 9. On attempts by the American Legion to require the American's Creed in schools, see Pierce, Citizen's Organizations, 42. The ABA created its own Citizenship Creed: "I believe that we Americans have the best government that has ever been created - the freest and the most just for all the people." Beale, Are American Teachers Free? 533. The "Ten Commandments of Patriotism," penned by two U. S. Navy officers, also circulated in conservative publications of the period. See "The Ten Commandments of Patriotism," Woman Patriot 17 \& 18 (September 1 and 15, 1922).

35. Wallace McCamant, Ethel Allen Murphy, and Nannie Lee Frayser, Constitution Week Celebration in Louisoille ([Louisville, Ky.: Constitution Week Committee], 1923), 5.

36. "An Inspiring Text," American Legion Weekly 1 (October 10, 1919). On the role of the American Legion in creating an ecumenical "religion of the nation," see Ebel, Faith in the Fight, 182-87.

37. Although a Christian term, in this essay "church" is intended to include institutions and practices from other religious traditions as well.

38. Bellah, "Civil Religion in America," 1.

39. See Sidney E. Mead, The Nation with the Soul of a Church (New York: Harper and Row, 1975); Conrad Cherry, God's New Israel: Religious Interpretations of American Destiny (Englewood Cliffs, N.J.: Prentice-Hall, 1971); and Ernest L. Tuveson, Redeemer Nation: The Idea of America's Millennial Role (Chicago: University of Chicago Press, 1968). See also Nathan O. Hatch, The Sacred Cause of Liberty: Republican Thought and the Millennium in Revolutionary New England (New Haven, Conn.: Yale University Press, 1977); Mark A. Noll, America's God: From Jonathan Edwards to Abraham Lincoln (Oxford, U.K.: Oxford University Press, 2002); and Amanda Porterfield, Conceived in Doubt: Religion and Politics in the New American Nation (Chicago: University of Chicago Press, 2012).

40. Haberski, God and War, 5. Catherine Albanese contends that in the United States, "civil religion is a recent name for religious nationalism." 
Catherine L. Albanese, America: Religions and Religion (Belmont, Calif.: Wadsworth Publishing Co., 1981), 283-309.

41. Angrosino, "Civil Religion Redux," 248.

42. John D. Wilsey, American Exceptionalism and Civil Religion: Assessing the History of an Idea (Downers Grove, Ill.: InterVarsity Press, 2015), 25.

43. See Ray H. Abrams, Preachers Present Arms: A Study of the War-Time Attitudes and Activities of the Churches and the Clergy in the United States, 1914-1918 (Philadelphia: Round Table Press, 1933); John F. Piper, Jr., The American Churches in World War I (Athens: Ohio University Press, 1985); and Shailer Mathews, Patriotism and Religion (New York: Macmillan Co., 1918).

44. See "All Creeds to Pay Honor to War Dead," New York Times, May 30, 1920.

45. See "Many to Preach on Patriotism," Los Angeles Times, February 20, 1921. See also "Prepare for Flag Day," Los Angeles Times, June 7, 1923; "Asked to Observe Constitution Day," Washington Post, August 7, 1921; and "Christian Church Fittingly Observes Independence Day," Atlanta Constitution, July 18, 1926.

46. "An Inspiring Text," 12. For background on the American Legion's National Americanism Commission and its programs, see William Pencak, For God and Country: The American Legion, 1919-1941 (Boston: Northeastern University Press, 1989), 3-23. Working together with the National Education Association and the United States Bureau of Education, the Legion also asked all religious groups to recognize the Sunday of Constitution Week as God and Country Day, with sermons "dealing with education and its relation to the service of God and country." "Special Sermons Start Local Education Week," Washington Post, November $19,1923$.

47. Cited from the Wheeling Intelligencer, June 20, 1922, in John C. Hennen, The Americanization of West Virginia: Creating a Modern Industrial State, 1916-1925 (Lexington: University Press of Kentucky, 1996), 136.

48. Annual Report of the Allied Patriotic Socieites, Inc., December 5, 1923, 3; Dwight Braham to Governors of the American States, January 16, 1923, both in American Civil Liberties Records and Publications (hereafter ACLU Records), Subgroup 1, Reel 52, Vol. 331. 
49. See "To Plead for Patriotism," Los Angeles Times, February 17, 1923. See also "Present Flag to Church," New York Times, April 15, 1929.

50. "Events of State Societies," Official Bulletin of the National Society of the Sons of the American Revolution 18 (1923): 49.

51. "Massing of Colors Brightens Fifth Avenue," New York Times, November 7, 1927.

52. "Jefferson-Franklin-Adams: These Men Who Drew Up the Declaration of Independence Were Unitarians," Los Angeles Times, July 3, 1926.

53. "Sermons of Patriotism Resound from Pulpits," Los Angeles Times, May 28, 1928. See also "Will Praise Constitution," Los Angeles Times, September 15, 1923.

54. S. I. Martin, "The American Legion and the Church," American Legion Weekly 4 (July 28, 1922): 25 . See also "Keeping Step with the Legion," American Legion Weekly 4 (October 20, 1922): 14, and "Legion Starts Drive to Enroll Every Ex-Yank," Chicago Daily Tribune, May 3, 1920.

55. See Hennen, Americanization of West Virginia, 136-37.

56. "'True Americans,"' Los Angeles Times, July 18, 1925. See also "Churches Observe Constitution Day," (Baltimore) Sun, September 17, 1923; "Divine Patriotism' Will Be Discussed at Second Baptist," Atlanta Constitution, November 6, 1926; and "Several Pastors to Preach on Flag and Father's Days," Washington Post, June 15, 1929. For a discussion of ethnic church civic celebrations in the postwar period, see June Granatir Alexander, Ethnic Pride, American Patriotism: Slovaks and Other New Immigrants in the Interwar Era (Philadelphia: Temple University Press, 2004). In 1921, the American Defense Society announced the celebration of America Day, to be celebrated each May 1 as a counterpoint to radical May Day activities, but the event never gained popular support. See "America Day to Spike Red Plan," (Louisville) Courier-Journal, April 21, 1921.

57. Cited in Jonathan Newell, "Billy Sunday's 1923 Evangelistic Campaign in Columbia, South Carolina," Proceedings of the South Carolina Historical Association, 2008 (Columbia: South Carolina Historical Association, 2008): 48.

58. "In Memoriam at Churches," Los Angeles Times, May 28, 1927. 
59. John Brittan Clark, The Red, or the Red, White and Blue (New York: American Defense Society, 1923), 7. The service was described by the American Defense Society as being part of "a vigorous campaign by the churches in behalf of Americanism and against Bolshevistic and revolutionary doctrines." Ibid., n.p.

60. "The Faith of the Founders," New York Times, July 5, 1926.

61. "Churches Observe Constitution Day," (Baltimore) Sun, September $17,1923$.

62. "Revive Prayer by Washington," Los Angeles Times, February 20,1926 .

63. Powell, Service for God and Country, 38.

64. "Flag Is Called Symbol of Ideals of This Nation," Nashville Tennessean, June 13, 1921.

65. On Bellah, see Gorski, "Barack Obama and Civil Religion," $181-83$.

66. Ira Chernus, "Civil Religion," in The Blackwell Companion to Religion in America, ed. Philip Goff (Chichester, U.K.: Blackwell Publishing, 2010), 67.

67. See Robert Wuthnow, "Divided We Fall: America's Two Civil Religions," Christian Century 115 (1988): 395-99, and Robert Wuthnow, The Restructuring of American Religion (Princeton, N.J.: Princeton University Press, 1988), 241-67. See also Martin Marty, "Two Kinds of Civil Religion," in Richey and Jones, American Civil Religion, 139-57.

68. See Grace Y. Kao and Jerome E. Copulsky, "The Pledge of Allegiance and the Meanings and Limits of Civil Religion," Journal of the American Academy of Religion 75 (2007): 121.

69. See Arthur Remillard, Southern Civil Religions: Imagining the Good Society in the Post-Reconstruction Era (Athens: University of Georgia Press, 2011).

70. Demerath and Williams, "Civil Religion in an Uncivil Society," $165-66 ; 166$.

71. See Gerald L. Sittser, A Cautious Patriotism: The American Churches and the Second World War (Chapel Hill: University of North 
Carolina Press, 1997), 17. See also Devere Allen, The Fight for Peace (New York: Macmillan Co., 1930), 47-54. On prewar religious opposition to preparedness, see Michael Kazin, War against War: The American Fight for Peace, 1914-1918 (New York: Simon \& Schuster, 2017), 99-103.

72. J. W. Shepherd, "Should Christians Engage in War?" Christian Leader 34 (July 20, 1920): 5. See Michael W. Casey, "From Pacifism to Patriotism: The Emergence of Civil Religion in the Churches of Christ during World War I," in The Stone-Campbell Movement: An International Religious Tradition, ed. Michael W. Casey and Douglas A. Foster (Knoxville: University of Tennessee Press, 2002), 472.

73. "Memorable Services at Nation's Capital," Federal Council Bulletin 5 (December 1921-January 1922): 15. "Patriotism is not enough," a statement made by the martyred British nurse Edith Cavell, was often quoted in antiwar sermons of the time. See, for example, "Thousands Honor Nation's Founders," New York Times, April 20, 1925. On multiple meanings attributed to the Tomb of the Unknown Soldier, see Jonathan H. Ebel, G. I. Messiahs: Soldiering, War, and American Civil Religion (New Haven, Conn.: Yale University Press, 2015), 46-68.

74. "For a Spiritual Meaning of Armistice Day," Federal Council Bulletin 5 (October-November 1922): 15.

75. "Says Memorial Day Arouses War Spirit," New York Times, May 27, 1929.

76. See Beale, Are American Teachers Free? 73; Ellis, To the Flag, 86-89; and Bessie Louise Pierce, Civic Attitudes in American School Textbooks (Chicago: University of Chicago Press, 1930), 241.

77. “Urges Christian Pacifism," New York Times, July 12, 1928.

78. See Roland Bainton, "The Churches and War: Historic Attitudes Toward Christian Participation," Social Action 11 (1945): 34.

79. See "Churches Unite for Disarmament," Federal Council Bulletin 4 (June-July 1921): 77. See also Sidney L. Gulick, The Christian Crusade for a Warless World (New York: Federal Council of the Churches of Christ in America, 1923), 163-64; Sittser, A Cautious Patriotism, 18-19; and Allen, The Fight for Peace, 47-54.

80. "Pressing for a Warless World," Federal Council Bulletin 4 (October-November 1921): 111-13. See also "Duty of the Churches," Federal Council Bulletin 5 (December 1921-January 1922): 22. 
81. See "Peace Sunday, June 5, To Be Observed Here," (Baltimore) Sun, May 21, 1921; "Churches to Observe Disarmament Sunday," (Baltimore) Sun, June 4, 1921; and Pierce, Citizens' Organizations, 147-49.

82. "What the Churches Can Do Now," Federal Council Bulletin 5 (February-March 1922): 13. See also "The Washington Conference," Homiletic Review 84 (January 1922): 113-14.

83. "The World Court Campaign Gains Momentum," Federal Council Bulletin 6 (November-December 1923): 3. See also "Churches Call America to Enter World Court," Federal Council Bulletin 6 (SeptemberOctober 1923): 3-4.

84. A. B. Kendall, "True Patriotism: What It Is and Does," Herald of Gospel Liberty 114 (October 5, 1922): 15.

85. "Sees World Remade by Woman in Politics," (Baltimore) Sun, October 4, 1920.

86. See "Churchgoers Hear Sermons on Labor," New York Times, September 5, 1921; "Pleas for Child Welfare Heard," (Louisville) Courier-Journal, January 30, 1922; "Labor Sunday Held in Churches of City," (Baltimore) Sum, September 3, 1923; "To Discuss Child Labor," New York Times, January 25, 1925; "Child Labor Ban Urged in Pulpits," New York Times, January 26, 1925; and "Labor Sunday Observance," Federal Council Bulletin 8 (September-October 1925): 28.

87. See "'Anti-Lynching Day' Is Set by Churches," New York Times, October 29, 1927.

88. "Eloquent Tribute Paid to Our Flag," Los Angeles Times, June $18,1923$.

89. "Plans New Bible of and for America," New York Times, February 28, 1924. See also "St. Mark's Reveres Stars and Stripes," New York Times, February 25, 1924.

90. See Gorski, American Covenant, 202-22. See also Murphy, "Civil Religion for a Diverse Polity," 226.

91. Rhys H. Williams, "Civil Religion and the Cultural Politics of National Identity in Obama's America," Journal for the Scientific Study of Religion 52 (2013): 254. 
92. Jonathan D. Sarna, "Forum: American Civil Religion Revisited," 21. See also Amanda Porterfield, ibid., 9-10; James G. Moseley, ibid., 17-18; and Sarna, ibid., 19-23.

93. "Calls Declaration Miracle of God," New York Times, July 5, 1926; "Holmes Asks New Declaration to Defy Capitalistic Control," New York Times, July 5, 1926.

94. "Memorial Sermons in Churches Today," New York Times, May 30, 1926. See also Sidney L. Gulick, "The Local Church in the Crusade for Peace," Federal Council Bulletin 7 (September-October 1924): 16.

95. See "Today's Programs in City's Churches," New York Times, January 27, 1929.

96. "Several Pastors to Preach on Flag and Father's Days," Washington Post, June 15, 1929.

97. "Thousands Honor Nation's Founders," New York Times, April 20, 1925.

98. "Fear Defense Day If It Glorifies War," New York Times, September 8, 1924. See also "Churches against Mobilization Day," Christian Century 41 (July 3, 1924): 862; "More Protests against Mobilization Day," Christian Century 41 (August 7, 1924): 1023; "Church Press against Mobilization Day," Christian Century 41 (August 7, 1924): 1028; and "The Trend of Events," Herald of Gospel Liberty 116 (September 25, 1924): 5.

99. "An Affront to the Church and to the Nation," Herald of Gospel Liberty 117 (May 21, 1925): 4.

100. "A Fourth of July Call to Sanity," Herald of Gospel Liberty 119 (June 30, 1927): 4. See "Veterans Protest Pacifist Memorial," New York Times, October 17, 1926. See also "Armistice Day: Contrasts and Contradictions," Federal Council Bulletin 10 (December 1927): 3-4.

101. "Americanism Recipe Is Given," (Louisville) Courier-Journal, April 29, 1920.

102. See "Pinks Rebuked by Evanston Rally," Chicago Daily Tribune, March 31, 1924. See also "No Insult to Flag, View of N.U. Faculty," Chicago Daily Tribune, March 25, 1924. 
103. "Legion Hits P.T.A. and Church Body," Atlanta Constitution, November 23, 1926. In 1928, American Legion officials also brought pressure on churches in the South to cancel speaking engagements by the pacifist Sherwood Eddy of the YMCA. See "Legion Will Try to Cut Pacifists" Audiences in U.S.," Atlanta Constitution, January 30, 1928. As late as 1929 , the organization was requesting public investigation of organizations with pacifist leanings, including the Federal Council of Churches. See "Legion Demands Pacifist Inquiry," New York Times, October 3, 1929.

104. "Bosheviki Bore into the Churches," New York Times, February 16, 1921; "Admits Attack on Interchurch Drive," New York Times, July 15, 1920. On Civic Federation claims of socialism in the churches, see "Socialism or Social Reform in the Church-Which?" National Civic Federation Review 5 (January 1, 1920): 15-20; T. Everett Harre, "Revolution in U.S. Preached to Methodist Clergy," National Civic Federation Review 5 (July 10, 1920): 11, 20-21; and "Purifying Politics-A Field for the Churches," National Civic Federation Review 5 (November 25, 1920): 14-15, 23-24. See also correspondence between Conde B. Pallen of the National Civic Federation and John A. Ryan, Director of the Department of Social Action of the National Catholic Welfare Conference, in ACLU Records, Subgroup 1, Reel 52, Vol. 331.

105. See Nielson, Un-American Womanhood, 124-30. The entire list is printed in ibid, 143-57. See also Delegard, Battling Miss Bolsheviki, 159-71.

106. "Calls on Columbia to Oust Professor Hayes," New York Times, January 17,1927 . In an earlier speech to the Committee on Militarism in Education, Hayes had decried the development of a "religion of nationalism" with its "shrines, images, icons, and relics," referring to the Liberty Bell and the "cult for worship of the flag, with very curious liturgical forms." See "Prof. Hayes Derides Patriotic Cults," New York Times, January 16, 1927. See also "Misquoted, Says Hayes," New York Times, January 18, 1927. See also Carlton J. H. Hayes, Essays on Nationalism (New York: Macmillan Co., 1928), 107-20.

107. See Beale, Are American Teachers Free? 73; Pierce, Civic Attitudes in American School Textbooks, 241; and Ellis, To the Flag, 86-89.

108. "Flays Churches for Armistice Day Message," Chicago Daily Tribune, November 9, 1926. See also "Legion Chaplain Condemns Church Attitude to War," Atlanta Constitution, August 6, 1924.

109. "Ministers Favor Preparedness; Decry Pacifism," Christian Century 43 (May 27, 1926): 690. 
110. "People Called to Stand for True Americanism," Los Angeles Times, January 21, 1924.

111. "Minister Calls Church Council Foe of Religion," Chicago Daily Tribune, April 25, 1927.

112. "Unpatriotic Intelligentsia," Moody Monthly 28 (July 1928): 519. The article was reprinted from the Better America Federation Bulletin. On patriotic nationalism in early fundamentalism, see George M. Marsden, Understanding Fundamentalism and Evangelicalism (Grand Rapids, Mich.: William B. Eerdmans Publishing Co., 1991), 50-53.

113. Frank D. Adams, "Dedicating the Living," Universalist Leader 25 (May 27, 1922): 5.

114. J. V. Moldenhawer, "Patriots and Christians," Federal Council Bulletin 12 (February 1929): 7-9. See also the comments of Episcopal Bishop Ashton Oldham in "Kellogg Lauds Church World Peace Efforts," Washington Post, October 22, 1928.

115. See, for example, "Methodist Conferences for Social Advance," Christian Century 44 (December 22, 1927): 1530.

116. "Who Are the True Patriots?" Federal Council Bulletin 11 (May 1928): 24.

117. "Fosdick Sees Honor in D.A.R. Blacklist," New York Times, May 28, 1928. See also "Baptists Denounce Blacklist Issued in 'Guise of Patriotism,"' Chicago Daily Tribune, June 19, 1928.

118. "Urges New Society to Offset D.A.R.," New York Times, April 23, 1928 .

119. See, for example, "Methodist Church Body Votes Refusal to Aid War," Washington Post, May 15, 1924; "Defense Day Is Deplored in M. E. Vote," Chicago Daily Tribune, October 4, 1924; "Lutheran Church for Just War," New York Times, October 28, 1924; "World Court Urged by Church Council; All Wars Decried," Washington Post, October 25, 1925; "Congregationalism Votes to Excommunicate War; Consolidate Boards," Christian Century 42 (November 5, 1925): 1385.

120. "Bishop Opposes Singing National Airs in Church," (Louisville) Courier-Journal, October 12, 1919. See also "Fears Patriot Songs Lack in Sacred Themes," Chicago Daily Tribune, October 12, 1919. 
121. "Flag Is Not above the Cross, He Says," New York Times, April 12, 1926. See also "Cross and Flag," Atlanta Constitution, May 17, 1926.

122. See "The Episcopal Convention," Washington Post, October 23, 1928. See also "Letters to Editor," Washington Post, October 21, 1928; "Bishops Adopt July 4 Service," New York Times, October 17, 1928; "Both Houses Adopt July $4^{\text {th }}$ Prayer," Washington Post, October 17, 1928.

123. "Bishop Freeman on the Symbolism of the American Flag," Washington Post, November 12, 1929. See "A Bishop's Insult," Washington Post, November 8, 1929.

124. "Pacifism Is Anarchy," Washington Post, May 10, 1925. See also "Pastor and Flock in Flag Dispute Agree to Part," Reading Times, April 30, 1925.

125. Philip E. Hammond, "Religion and the 'Informing' of Culture," Journal for the Scientific Study of Religion 1 (1963): 103.

126. See Ronald C. Wimberley and James A. Christenson, "Civil Religion and Church and State," Sociological Quarterly 21 (1980): 38.

127. See Ronald C. Wimberley, "Civil Religion and the Choice for President," Social Forces 59 (1980): 44-61, and Ronald C. Wimberley and James A. Christenson, "Civil Religion, Social Indicators, and Public Policy," Social Indicators Research 10 (1982): 211-13.

128. See, for example, Christopher B. Chapp, Religious Rhetoric and American Politics: The Endurance of Civil Religion in Electoral Campaigns (Ithaca, N.Y.: Cornell University Press, 2012); Andrew Michael Manis, Southern Civil Religions in Conflict: Civil Rights and the Culture Wars (Macon, Ga.: Mercer University Press, 2002); and Walter A. McDougall, The Tragedy of U.S. Foreign Policy: How America's Civil Religion Betrayed the National Interest (New Haven, Conn.: Yale University Press, 2016).

129. I'orterfield, "Forum: American Civil Religion Revisited," 11.

130. "Pertinent Pulpit Paragraphs," Los Angeles Times, June 21, 1920.

131. "Minister's Speech for Harding Stirs Methodist Pastors," Chicago Daily Tribune, July 15, 1920. For other examples, see "Dr. Wise Advocates Coolidge's Defeat," New York Times, November 3, 1924; "Memorial Services Held in Churches," New York Times, November 12, 1927; and "Coolidge Navy Plan Assailed by Pastor," New York Times, November 19, 1928. 
132. See "The Church and the Voter," Homiletic Review 88 (June 1924): 456. See also Liette Gidlow, The Big Vote: Gender, Consumer Culture, and the Politics of Exclusion, 1890s-1920s (Baltimore, Md.: Johns Hopkins University Press, 2004), 51-52.

133. "Pastors Urged To Get Voters to the Polls," Washington Post, October 4, 1924. See Worth M. Tippy, "Get Out the Vote!" Federal Council Bulletin 7 (September-October 1924): 12.

134. "The Church and the Voter," Homiletic Review 88 (July 1924): 6. Church members were also asked to take a "Voter's Pledge" promising to register and vote. See "The Church and the Voter," Homiletic Review 88 (October 1924): 264-69. The Christian Herald, an interdenominational publication, advised churches to set aside a portion of their service on Sunday, October 26, for a discussion of the duties of citizenship. It also offered the church in each state with the highest percentage of voters a trip to the inauguration and "a handsome pulpit Bible, suitably inscribed." "Getting Out the Christian Vote," Christian Herald 47 (September 27, 1924): 787 .

135. "Predicts Passing of Slacker Voters," New York Times, November 9, 1924.

136. On the partisan character of the campaign, see Michael E. McGerr, The Decline of Popular Politics: The American North, 1865-1928 (New York: Oxford University Press, 1986), 195-97.

137. "Pledged-2,000,000 Ballots in Homiletic's Campaign," Homiletic Review 88 (November 1924): 358.

138. See "Dry Convention Closes," New York Times, September 20, 1920. Preaching on Second Constitution Day, in 1926, to delegates of the Woman's Christian Temperance Union meeting in Los Angeles, Methodist pastor E. E. Helms described those advocating proposals to permit the states to hold referenda allowing the sale of alcohol as "traitors to our Constitution." ("While true Americans sing "The Star Spangled Banner, "' Helms told his audience, "traitors to our Constitution are singing "How Dry I Am!"”) "Opposers of Nation's Law Denounced as Traitors," Los Angeles Times, September 27, 1926.

139. "Plea by Manning for the Dry Laws," New York Times, February 23, 1925. See also "Law Breakers Held Unfit to Honor Dead," New York Times, May 28, 1928; "Today's Programs in City's Churches," New York Times, June 30, 1929. 
140. "Drys Will Appeal to Church Members," New York Times, October 1, 1928.

141. "Loyalty Crusade Planned," Los Angeles Times, August 23, 1929. See also "Join in Church Plea for Respect for Law," New York Times, July 1, 1929.

142. "Ruth Bryan Owen Urges Dry Pledge as Ritual of Flag," Washington Post, April 15, 1929.

143. See "Ku Klux Call at Church on Bid of Pastor," (Baltimore) Sun, April 17, 1922; "Ku Klux Enter Church Tent; Have Paper Read," (Louisville) Courier-Journal, September 24, 1922; "Ku Klux Klansmen Invade a Church," New York Times, October 23, 1922; "Church Split by Act of Ku Klux," (Louisville) Courier-Journal, November 19, 1922; "Ku Klux Klansmen March into Church," New York Times, December 19, 1922. For pastors who opposed Klan participation in services, see "Preacher Says Klan Can't Hide Sins in Church," Chicago Daily Tribune, April 9, 1923, and "Pastor Berates Klansmen on False Americanism," Chicago Defender, September 19, 1925. On the anti-Smith campaign in the South, see Kenneth K. Bailey, Southern White Protestantism in the Twentieth Century (New York: Harper \& Row, 1964), 92-110.

144. Cited in Isidor Wise, "'Over the Devil's Back," American Israelite, August 26, 1926.

145. "Pastor Holds It Duty of Pulpit to Talk Politics," Los Angeles Times, October 22, 1928.

146. "All Saloons in World to Go If Hoover Wins, Says Sunday," Washington Post, November 3, 1928.

147. "Nation to Observe Flag Day June 14," New York Times, June $5,1927$.

148. "Leaders in 3 Faiths Urge Clergy to Aid in Flag Observance," Washington Post, May 29, 1927.

149. See "Washington Urged Religious Concord," New York Times, February 20, 1928; "Extol Washington in Diverse Tribute," New York Times, February 23, 1928; and "Smith and Hoover Praised by Robbins," New York Times, July 2, 1928 .

150. "Deputies Name Dr. Phillips as Head of House," Washington Post, October 11, 1928. See also "Ministers Attack Campaign Bigotry," New York Times, October 8, 1928. 
151. "Dr. Wise Sees Smith Hit by 'Unholy War,'” New York Times, October 1, 1928.

152. "Ceremonies in City Honor Columbus," New York Times, October 12, 1928.

153. "Van Dyke Assails Campaign Bigotry," New York Times, September 2, 1928.

154. See Charles Palmerston Anderson, "The Church and the World," Federal Council Bulletin 11 (November 1928): 5. On the consequences of the campaign for southern white Protestant churches, see Bailey, Southern White Protestantism, 107-10.

155. See "Vast Crowd Honors Flag at Ceremony," Washington Post, June 10, 1929.

156. "Hoover Inspires Sermons," Los Angeles Times, March 2, 1929.

157. "Says Memorial Day Arouses War Spirit." See also "Obedience to Law Is Urged by Bishop," Washington Post, May 27, 1929.

158. "Roosevelt Assails Militaristic Patriot," New York Times, November 11, 1929. See also Ronald Isetti, "The Moneychangers of the Temple: FDR, American Civil Religion, and the New Deal," Presidential Studies Quarterly 26 (1966): 678-93.

159. Bellah, The Broken Covenant, 142. See also Bellah, "Civil Religion in America," 16-19.

160. See Williams and Fuist, "Civil Religion and National Politics in a Neoliberal Era," 932-35.

161. Roof, "American Presidential Rhetoric from Ronald Reagan to George W. Bush," 300.

162. On the national anthem, motto, and pledge, see Richard V. Pierard, "The Role of Civil Religion in American Society," in Oxford Handbook of Church and State in the United States, ed. Derek K. Davis (Oxford, U.K.: Oxford University Press, 2010), 490-92. See also Kevin M. Kruse, One Nation Under God: How Corporate America Invented Christian America (New York: Basic Books, 2015). On new memorials, see Peter Gardella, American Civil Religion: What Americans Hold Sacred (New York: Oxford University Press, 2014), 323-44. On civil religion and presidential rhetoric, see David Domke and Kevin Coe, The God Strategy: How Religion Became a Political Weapon in America (New York: Oxford University Press, 2010), 61-64. 
163. See Angrosino, "Civil Religion Redux," 260-65.

164. See Kruse, One Nation under God, 165-294.

165. See Haberski, God and War, 243-54.

166. See Andrew R. Murphy and David S. Gutterman, Political Religion and Religious Politics: Navigating Identities in the United States (New York: Routledge, 2016), 22-49; Gerald R. Webster and Jonathan I. Leib, "Religion, Murder, and the Confederate Battle Flag in South Carolina," Southeastern Geographer 56 (2016): 29-37; and Arthur Remillard, "Protests, Pigskin, and Patriotism: Colin Kaepernick and America's Civil Religions," OUPblog, September 17, 2016, http://blog.oup.com/2016/09/patriotismkaepernick-america-religions/.

a BSTRACT Since the publication fifty years ago of Robert N. Bellah's classic article "Civil Religion in America," the concept of civil religion has provoked continuing debates among scholars who study religion and American culture. This essay is a contribution to these debates and an attempt to move beyond them. It considers American civil religion as theory and as practice, examining its meaning through an investigation of how it functioned at an important and too little studied point in its past. Arguing that civil religion is both a cultural and a political construct, it shows how at the close of World War I, a loosely linked network of civic, military, and patriotic groups came together to create a sacralized form of patriotic nationalism and incorporate it into the American civil religious tradition. Contending that the relationships between civil religion and more conventional forms of organized religion are often close and at times contentious, it examines how religious bodies of the time were instrumental in supporting this process and intractable in resisting it. Proposing that civil religion can come in a variety of sometimes competing versions, it discusses the conflicts over civil religious practices that ensued within American churches during the next decade, relying on reports from the time to describe how these conflicts divided church leaders, denominations, and congregations. Finally, working from the premise that civil religious beliefs, symbols, and rituals are invariably involved in the political process, it examines how they became increasingly used for partisan purposes over the course of the decade, raising issues about the relationship between church and state. In closing, it comments on the enduring character of civil religion, and speculates on its continuing importance for American religion and politics.

Keywords: Robert N. Bellah, civil religion, patriotic nationalism, United States history 